\title{
Network analysis and inter-ecosystem comparison of two intertidal mudflat food webs (Brouage Mudflat and Aiguillon Cove, SW France)
}

\author{
Delphine Leguerrier ${ }^{\mathrm{a}}$, Delphine Degré ${ }^{\mathrm{a}, \mathrm{b}}$ and Nathalie Niquil ${ }^{\mathrm{a},{ }^{*}}$
}

\begin{abstract}
${ }^{a}$ Centre de Recherche sur les Ecosystèmes Littoraux Anthropisés (CRELA, UMR 6217 CNRS-IFREMERUniversité de La Rochelle), Pôle Sciences et Technologie, avenue Michel Crépeau, 17042 La Rochelle Cedex 1, France

${ }^{b}$ Office National de la Chasse et de la Faune Sauvage, Réserve Naturelle de la Baie de l'Aiguillon, Ferme de la Prée Mizottière, 85450 Sainte-Radegonde des Noyers, France

*: Corresponding author : Niquil N., email address : nniquil@univ-Ir.fr
\end{abstract}

\begin{abstract}
:
Network analysis was used to analyse steady-state models of the food webs of two intertidal mudflat ecosystems: Aiguillon Cove and Brouage Mudflat, on the South-Western Atlantic Coast of France. The aim was to highlight emergent properties of food-web functioning in these two ecosystems and to compare these properties with other coastal ecosystems. Both ecosystems imported detritus in parallel to a high benthic primary production. They were characterised by a high diversity of resources. Both also exported living material, leading to a high quality production, quantified as export of Exergy. This export was mainly composed of cultivated bivalves during the cold season for Brouage Mudflat, and of the migration of grazing fish in Aiguillon Cove during the warm season. Their internal organization was characterised by short pathways, high recycling, high redundancy and low net ecosystem production, compared to the other systems selected. These characteristics, encountered in many estuaries, presented less extreme values.
\end{abstract}

Keywords: food web; ecosystem comparison; inverse analysis; network analysis; intertidal mudflat; Atlantic coast 
In coastal management, it is necessary to have an overview of ecosystem functioning which is necessarily done through a holistic description (Jørgensen and Müller, 2000a). One way to gather all the information on an ecosystem's biocenosis and assess the relationships between its various components is to build its food web (Winemiller and Polis, 1996). As it is difficult to comprehend the nature of complex food webs through direct observation, indices characterizing food web properties through an overall vision of its structure and its functioning have been developed (Ulanowicz, 1986; Kay et al., 1989).

The aims of network analysis indices are to characterise the overall structure of the ecosystem and to assess both direct and indirect relationships between compartments (Szyrmer and Ulanowicz, 1987). A "goal function" is supposed to tend to an optimum as the system evolves (Bendoricchio and Jørgensen, 1997), but if there is a preferred state or goal for the ecosystem, it is not often well defined (Fath, 2004). Various hypotheses have been proposed, such as a maximizing Power output (Lotka 1924 in Bendoricchio and Jørgensen, 1997; Odum and Pinkerton, 1955), Ascendency (Ulanowicz 1986), Emergy (Odum 1988), Exergy (stored, Jørgensen 1999 or dissipated, Schneider and Kay 1994), ratio of Emergy/Exergy (Bastianoni and Marchettini 1997). Many properties of the ecosystems, in terms of energy utilization, organization, synergism, or homogenization due to indirect effects have also been used (Higashi et al. 1993, Patten 1995, Fath and Patten 1998, 1999). Exergy, Emergy, Power, Ascendency and indirect effects seem to present a common basis (Patten 1995). Even though they cannot be unified in one single theory (Jørgensen and Müller, 2000b), they are mutually consistent (Fath et al., 2001). They can then be used to compare ecosystems and to describe their relative evolutions. Indeed, considering that the mean ecosystem computed as a static food web represents a stabilized system under certain constraints, it is possible to compute some indices on the basis of some goal functions (adapted originally to study the evolution of simulation models or to evaluate systems, e.g. Exergy - Marques et al., 1997; Fath et al., 2004). Baird et al. (1991) showed that ecosystem comparison based on network analysis indices can be used for a better characterization of ecosystems.

European intertidal mudflats are among the most biologically productive areas in the world (McLusky and Elliott, 2004). Along the French Atlantic coast, Aiguillon Cove and Brouage Mudflat are macrotidal ecosystems mainly composed of extended mudflats. They are similar in terms of their benthic fauna. Both are major European sites for shellfish (oyster and mussel) culture (Goulletquer and Le Moine, 2002). They differ by the presence of a salt-marsh adjacent to the large mudflat in Aiguillon Cove, absent in Brouage, and by the extension of the shellfish structures, much more extended in Brouage than in Aiguillon Cove. The shape of the coast and the location of rivers also present differences. Aiguillon Cove has a longer residence time and a direct river input, differing from the Brouage Mudflat.

In this study, we examined how these similarities and differences impacted food web functioning. This functioning was characterised through the calculation of network analysis indices and was compared between the two sites. In order to place these results in the context of coastal ecosystems in general, network indices from AC and BM were then compared to those of published food webs from the literature that had similar structures. Our hypothesis was that these two European type soft-bottom semi-enclosed coastal ecosystems, under estuarine influence, would have common characteristics, but that their slight, especially morphological, differences would also result in differences in food-web functioning, which could be elucidated by a network analysis approach.

The Brouage Mudflat has been annually modelled by Leguerrier et al. $(2003,2004)$, and compared to Aiguillon Cove by a direct observation of the food-web flows (Degré et al., 2006). The method used for estimating missing values of the carbon flows was inverse analysis (Vézina and Platt, 1988). Degré et al. (2006) modified this approach for coupling two seasons. Based on ecological modifications of the communities, the "summer" season was defined as mid-March to mid-October, and the "winter" season as the rest of the year.

The objective of the present paper was to go further in the trophic functioning description of these two close ecosystems. Network indices (Ulanowicz, 1986; Kay et al., 1989) of these two food webs were estimated and used to compare the functioning of these systems between summer and winter. Then indices were calculated on a mean annual basis and compared to computable or published indices in several food webs models available in marine scientific literature. 


\section{Material and Methods}

\subsection{Study sites and model construction}

[Figure 1]

Located on the South-Western Atlantic French coast (Figure 1), the Charentais Sounds (Pertuis) are semi enclosed macrotidal areas protected from the ocean influence by islands (Ile de Ré and lle d'Oléron) and influenced by estuarine transport through the Charente and Sèvre Niortaise rivers. They are characterized by the presence of large mudflats, which are the sites of an extensive shellfish culture (Goulletquer and Héral, 1997), juvenile fish nurseries (Le Pape et al., 2003) and feeding grounds for wintering shorebirds (Triplet et al., 2001).

The Brouage mudflat is located on the eastern part of the Marennes-Oléron Bay. It covers 40 $\mathrm{km}^{2}$ (Gouleau et al., 2000); with a flat bottom slope (1:1000) and a very wide (4.5 km) tidal area. The current speed varies from 0.2 to $0.6 \mathrm{~m} \mathrm{~s}^{-1}$ (Bassoullet et al., 2000; Le Hir et al., 2000). Oyster culture on racks covers $16 \%$ of the intertidal area, located on the lower part (Lemoine, pers. comm.).

The Aiguillon Cove is a large intertidal area (Verger, 1968), constituted mainly of large mudflats $\left(33 \mathrm{~km}^{2}\right)$ and surrounded by salt-marshes $\left(11 \mathrm{~km}^{2}\right)$. This cove is a semi-circular sedimentation basin for silts and clays (Verger, 1968). It has a gentler bottom slope and a larger mudflat on the southern than of the northern part (1.5:1000 vs. 1.8:1000 and 3.5 vs. $3 \mathrm{~km}$, respectively). Current speeds average $0.2-0.6 \mathrm{~m} \mathrm{~s}^{-1}$ (SHOM, 2001). The mudflat was considered as composed of $97 \%$ of "free" mudflat, $2 \%$ of mussel cultures and $1 \%$ of oyster racks.

A previous study of these two systems (Degré et al., 2006) estimated carbon flows on an average square meter of mudflat using inverse analysis. Two seasons ("summer": mid-March to mid-October, and "winter": the rest of the year) were distinguished. This partition has been chosen to take into account: (1) the wintering of migratory birds (which arrive in October and depart by March); (2) the gastropoda Hydrobia ulvae, which begin to reproduce in March (Haubois et al., 2004); (3) the nematodes, which are more numerous in winter (Rzeznik-Orignac et al., 2003); and (4) the microphytobenthos which usually begins their high primary production in March (Guarini et al., 2004).

The inverse analysis, as developed by Vézina and Platt (1988), was adapted by Degré et al. (2006) in order to compute simultaneously the two seasonal food webs. Biomass was considered constant over the annual period. A biomass variation was considered between the two seasons, when documented. Available information on the flows included field estimates (e.g. bacterial production), experiments (e.g. grazing of diatoms by nematods) and validatedmodel results (net primary production). The input and output flows of plankton and detritus by hydrodynamic transport were estimated using simple physical equations. Unknown flows were constrained with inequalities from literature data.

In the Aiguillon Cove and the Brouage Mudflat, Degré et al. (2006) described 16 compartments: microphytobenthos, phytoplankton and resuspended microphytobenthos, benthic foraminifers, nematodes, bivalves (mainly Scrobicularia plana and Macoma balthica), annelids (mainly Hediste diversicolor, Neanthes succinea and Nephtys hombergii), gastropods (mainly Hydrobia ulvae), arthropods, shellfish culture (Crassostrea gigas in the Brouage mudflat and Mytilus edulis in the Aiguillon cove), pelagic microzooplankton (ciliates and flagellates), mesozooplankton (mainly copepods), fish juveniles (mainly carnivorous fishes, especially juvenile flat fish Solea solea), adult grazing fish (mainly mullet Liza ramada), and shorebirds (mainly Dunlins Calidris alpina, Knot Calidris canutus and black-tailed Godwit Limosa limosa), and benthic and pelagic detritus, which also include the free and attached bacteria.

A total of 106 carbon flows (see Figure 3 in Degré et al., 2006) were calculated between the compartments. The same food web structure was taken into account in summer and in winter. Because there was more extensive data for the Brouage Mudflat, the conceptual models of inverse analysis were slightly different: the BM detritus compartments were divided into dissolved organic carbon (DOC), particulate organic carbon (POC) and bacteria. Then, these 3 compartments were aggregated for the Network Analysis, so that the structure of the model would be the same in the 2 studied ecosystems. 


\title{
1.2. Inter-ecosystem comparisons
}

\author{
[Figure 2] [Table 1]
}

In order to compare the functioning of the 2 French intertidal mudflats with other ecosystems, 14 coastal sites were chosen (Table 1, Figure 2), according to the availability in the literature of a static model either built with inverse analysis (Vézina and Platt, 1989) or with ECOPATH (Christensen and Pauly, 1992) and that coupled benthic and pelagic layers. All models were annually averaged. Biomass-based model values were converted into gC with the assumption that $1 \mathrm{~g}$ wet weight $=0.04 \mathrm{Gc}$. All results are expressed in $\mathrm{gC} \cdot \mathrm{m}^{-2} \cdot \mathrm{y}^{-1}$. Models were selected according to their level of aggregation of species into compartments considered similar to the one of the French mudflats. The models chosen had from 12 to 24 compartments. More detailed models (St Mark in the Apalachee Bay, in Florida, 51 compartments, Baird et al., 1998; Sylt-Rømø Bight, Wadden Sea, 59 compartments, Baird et al., 2004) were included in the discussion for the indices that were less sensitive to the model structure, but they were excluded from the quantitative analysis in order to limit structural differences between the studied models.

[Three upwelling systems were selected. The Peruvian upwelling system (Figure 2) is a part of the larger Humbolt Current System in the south-western Pacific (Baird et al., 1991). It supports one of the most productive fisheries in the world (Baird et al., 1991). The Benguela upwelling system is situated along the West coast of Africa in the South-East Atlantic Ocean (Heymans et al., 2004). The northern Benguela ecosystem is bounded by the Angolan gyre in the north and by the Lüderitz upwelling centre in the south. The Tongoy Bay is located in the management area of Puerto Aldea, Chile. Four subtidal habitats from Tongoy Bay were studied (Ortiz and Wolff, 2002): (1) seagrass meadows from 0 to $4 \mathrm{~m}$ depth, (2) sand-gravel between 4 and $10 \mathrm{~m}$, (3) sand between 10 and $14 \mathrm{~m}$, and (4) mud > $14 \mathrm{~m}$ depth.

The two African estuaries are located (Baird and Ulanowicz, 1993) on the Indian Ocean coasts. The Swartkops estuary discharges into the Indian Ocean through a constricted inlet. The estuary is small $\left(4 \mathrm{~km}^{2}\right.$, with $1.82 \mathrm{~km}^{2}$ of Spartina maritima dominated salt marshes), shallow (1.6 $\mathrm{m}$ of tidal amplitude), turbid and well-mixed (Baird and Ulanowicz, 1993). The Kromme estuary discharges into the St Francis Bay through a constricted inlet. The estuary is small (3 $\mathrm{km}^{2}$, with $0.8 \mathrm{~km}^{2}$ of Spartina maritima dominated salt marshes), shallow (1.6 $\mathrm{m}$ of tidal amplitude), and well-mixed (Baird and Ulanowicz, 1993).

Three American estuaries were compared (Monaco and Ulanowicz, 1997), all of which are under anthropgenic influence. While the Narragansett Bay has three entrances from west to east: the West Passage, the East Passage, and the Sakonnet River, the Delaware Bay mixes freshwater from the Schuylkill River at the port of Philadelphia with salt water from the Atlantic Ocean at Cape May and Cape Henlopen. The Chesapeake Bay is the largest drowned river valley estuary in the USA (Baird et al., 1991). The mesohaline region, studied by Baird et al. (1991), encompasses about $48 \%$ of the total area of the Bay and receives large amounts of pollutants and nutrients in runoff.

The brackish Baltic Sea is characterized by a latitudinal gradient of salinity, nutrients, hydrographic conditions, temperature and light intensity, that influences abundance, distribution, composition and diversity of species. Sandberg et al. (2000) compared three sites of the Baltic Sea: the low saline and oligotrophic Bothnian Bay, the Bothnian Sea and the Baltic proper, where salinity and nutrient levels are higher.

Three European estuaries were included in the comparison. The Ythan estuary, located about $20 \mathrm{~km}$ north of Aberdeen, Scotland, is a maximum $620 \mathrm{~m}$ wide estuary. The habitats studied by Baird and Milne (1981) are comprised of 71 ha of subtidal areas and 185 ha of intertidal areas (115 ha of mud and mud-sand mixture, particularly in upper reaches, and 70 ha of sand, mussels beds, and stones, particularly in mouth and lower reaches). Baird and Ulanowicz (1993) studied the whole Ythan estuary that receives about $2000 \mathrm{~m}^{3}$ of primary treated sewage per day from upstream towns. The Ems estuary is a shallow semi-diurnal tidal estuary draining into the Wadden Sea, including $245.7 \mathrm{~km}^{2}$ of large tidal flats composed by sand in the mouth and clay sediment in the middle and upper reaches (Baird and Ulanowicz, 1993). The Ems estuary (Baird et al., 1991) exhibits gradients of tidal amplitude and salinity. It receives large amounts of nutrients, but shows little eutrophication or pollution. The Seine Estuary is located at the interface between the French River Seine and the Eastern Channel (Rybarczyck and Elkaïm, 2003). The downstream sector with mudflats (polyhaline or mesohaline, 10-25\%o) is separated from the upstream sector (mesohaline or oligohaline, 0.5-10\%), near Honfleur.] 


\subsection{Synthetic Indices}

\subsubsection{Throughput and production indices}

The Total System Throughput (TST) of an ecosystem is the sum of all its fluxes and hence depends on the aggregation level chosen for its representation (Kay et al., 1989). The Net System Production ( $\mathrm{gC} \cdot \mathrm{m}^{-2} \cdot \mathrm{y}^{-1}$ ) is the sum of all migratory (i.e. not the gross primary production) inputs to the system minus all the exports of the system (Rybarczyk and Elkaïm, 2003). Based on Exergy (Jørgensen et al., 1995) goal functions, we established an index that defines the qualitative assessment of exchanges with the outside of the systems. We called it Net System Quality Production (units of energy). It was computed by multiplying each of those exchange fluxes by a coefficient representing the quality of the material involved in Exergy computation (Jørgensen et al., 1995). The Detritivory/Herbivory ratio was also computed.

\subsubsection{Cycling and trophic indices}

Other indices attempt to summarise all the possible pathways between compartments, and hence are based on the calculation of the integral interaction matrix which accounts for both direct and indirect relations between compartments: the Leontief matrix (Szyrmer and Ulanowicz, 1987). Based on this matrix, various indices can be computed, among which Average Path Length (APL) and the Finn Cycling Index (FCI). The APL (Finn, 1976) represents the mean number of steps that a particle entering the system will take before exiting. Originally, the $\mathrm{FCl}$ (Finn, 1976) gave the proportion of material cycling in the system versus straightforward flows that do not cycle. It was reformulated by Ulanowicz (1986) who chose to normalize it by the TST and computed it by removing one by one the cycling elements of the networks, hence calculating also the number of cycles and their average length.

The Lindeman representation of a food web aims to visualize it as a food chain (Lindeman, 1942), with primary producers and detritus at the first level. According to their diets, compartments are dispatched amongst integer number Trophic Levels between which Transfer Efficiencies can be computed (Ulanowicz, 1986). Compartments are also given an index which represents their average Trophic Level.

\subsubsection{Energy flowing indices}

The use of thermodynamic functions has allowed energy flowing thorough ecosystems to be quantified. Ascendency $(A)$ is a measure of the amount of information flowing within a system, multiplied by the TST (Ulanowicz, 1986). Its upper bound is the Development Capacity (C) and the gap between the two is composed of 'overheads': on imports, on exports, dissipative (respiratory) and pathway redundancy (Ulanowicz, 1997). Relative Ascendency (A/C), relative Redundancy (Redundancy/C) and internal relative Ascendency (Ascendency/internal Development Capacity) were also calculated.

\subsubsection{Inter-ecosystem comparisons}

The comparisons focused on two 2-dimensional indices: Net System Production and Net System Quality Production, and non-dimensional indices: $\mathrm{FCl}$, Detritivory / Herbivory ratio, Primary Production Efficiency (net primary production / herbivory), relative Ascendency and Redundancy, internal relative Ascendency, Net Primary Production / total Biomass (productivity), Gross Primary Production / total System Respiration, APL and number of trophic level. When possible, indices have been computed from results described in the articles, either using netwrk.exe ${ }^{\circledR}$ (Ulanowicz, 1999: http://www.cbl.umces.edu/ ulan/ntwk/network.html) concerning the counting of cycles within the food webs), or by direct calculation from indices described above, when they were recorded, or flux-diagram results when they were precise enough.

To examine the relationships between the indices and to characterise the different ecosystems, Spearman rank correlations were calculated and a principal component analysis (PCA) was performed on the table of the indices for the different ecosystems. In order to suppress missing values, the Tongoy Bay and Northern Benguela upwelling were not taken into account in these 
analysis, nor the number of trophic levels and the primary production efficiency. These analyses were performed with XLSTAT ${ }^{\odot}$.

\section{Results}

\subsection{Comparison of the two seasons in the two French intertidal mudflats}

[Table 2]

The Brouage Mudflat showed two contrasting seasons (Table 2). The contrast between summer and winter was higher in Brouage Mudflat than in Aiguillon Cove for the net system quality production and for all the non-dimensional indices computed (FCl, Detritivory/Herbivory, relative Ascendency and Redundancy, internal relative Ascendency, APL and number of trophic levels). The net system production was negative for both seasons in the two systems. The net system import was higher (higher absolute values) in Aiguillon Cove than in Brouage Mudflat. For each site, the net system import was higher in summer than in winter.

The enrichment in high quality material (measured by net system quality production) observed was not the same either: while Aiguillon Cove exports were more enriched during summer than winter, it was the opposite in Brouage Mudflat. In Brouage, the high winter quality production was connected to the seasonality of the oyster production, mainly harvested in winter, and in Aiguillon, with the high migration of grazing fish in summer.

The Brouage Mudflat was characterised, from summer to winter, by the decrease of APL, FCI, number and length of cycles, and number of trophic levels and the increase in $A / C$, internal relative Ascendency and Net System Quality Production, while these indices were equivalent for the two seasons in Aiguillon Cove. The difference between A/C and internal relative Ascendency was similar in Brouage Mudflat and Aiguillon Cove during the two seasons.

Different pathways occurred during the two seasons for Brouage Mudflat, whereas the diets of each compartment remained approximately the same in Aiguillon Cove. The nekton juveniles in Aiguillon Cove, for instance, had a diet exclusively composed of bivalves, while they changed their diet at Brouage Mudflat from predation of $50 \%$ on bivalves, $25 \%$ on gastropods, and $25 \%$ on arthropods in summer, to $75 \%$ on bivalves and $25 \%$ on gastropods in winter (Degré et al., 2006). Grazing fish from Aiguillon Cove had a mixed diet of microphytobenthos and detritus at both seasons, while at Brouage Mudflat they switched from an exclusively herbivorous diet in summer to prey on nematofauna in winter. They then entered into competition with carnivorous annelids. Overall, diets were more based on detritus than on primary production, with a Detritivory/Herbivory ratio higher in winter than in summer for the two ecosystems.

The loss of one Trophic Level and increase of the Trophic Efficiency from level 2 to level 3 was due to the combined decrease production efficiency of annelids and increase in that of the nematodes: there was a change in the carbon pathways in Brouage Mudflat, which did not occur in Aiguillon Cove. Indeed, the nematode populations were more numerous in winter than in summer in Brouage (Rzeznik-Orignac et al., 2003), contrary to what is observed for macrofauna.

\subsection{Annual properties and inter-ecosystem comparisons}

[Table 3]

The annual models of Brouage Mudflat and Aiguillon Cove were compared to several ecosystems from the literature (Table 3). Brouage Mudflat and Aiguillon Cove had a very low Net System Production. These negative values were due to high material import mainly composed of detritus. Negative values were also found for Swartkops estuary, Kromme estuary and Chesapeake Bay. In contrast, the Net System Quality Production was very high compared to the other systems. This corresponded to the export of living material (phytoplankton, zooplankton, bird, fish and commercial export of bivalve production).

Brouage Mudflat and Aiguillon Cove were characterised by short pathways as shown by the low values of Average Path Length and number of trophic levels. These two indices presented wide variations among ecosystems, and even among estuaries.

The recycling intensity in Brouage Mudflat and Aiguillon Cove, measured by $\mathrm{FCl}$, was close to the mean value of the different ecosystems. Estuaries were the most highly recycling systems. Compared to them, the $\mathrm{FCl}$ of Brouage Mudflat and Aiguillon Cove was low. 
Concerning Detritivory/Herbivory, the values in Brouage Mudflat and Aiguillon Cove were close to the mean value. Most of the high values were encountered in estuaries.

Brouage Mudflat and Aiguillon Cove had values of $A / C$ lower than the mean value. These values were in the lower part of the range covered by estuaries. The Relative Redundancy or importance of parallel pathways inside the food web was high in Brouage Mudflat and Aiguillon Cove, as for most of the other estuaries.

The Brouage Mudflat and Aiguillon Cove presented a high value of productivity and this primary production was efficiently driven to herbivores (high Primary Production Efficiency values).

[Table 4]

The correlation matrix between all network indices (Table 4) presented a complex pattern of interactions. The strong negative correlation between Relative Ascendency and Redundancy was directly linked to the calculation of these indices. The same was true for the positive correlation between total Relative Ascendency and internal Relative Ascendency. The negative correlation observed between productivity and $\mathrm{FCl}$ could be related to the fact that recycling and matter input were the two possible ways of increasing the flows in a system (Borrett and Osidele, 2006). Moreover, the recycling (FCl), by decreasing the proportion of the flows derived from the production, increased the APL (Christensen, 1995; Borrett and Osidele, 2006). FCI was also positively related to redundancy, expressed as its ratio to development capacity. The gross primary production/respiration naturally correlated to Net System Production, and was negatively correlated to Detritivory /Herbivory as a high gross primary production enhances herbivory. The net system production also positively correlated with internal Ascendency, which could correspond either to a enhancement of internal flows or of their organisation. Cycling played a central role in the multiple correlations observes (Borrett and Osidele, 2006).

The principal component analysis of these indices constructed a first component (34\% of the variance) positively correlated with recycling $(\mathrm{FCl}$ contributed to $16 \%$ of the variance and was the dominating factor in the first axis construction), and redundancy (contribution: 14\%) and negatively correlated to Ascendency (13\%) and the net system production (13\%). On the first axis, all estuaries models were located on the right hand side, with the exception of the first Ythan model and the Seine model. This corresponded to the fact that most of the estuaries presented a high $\mathrm{FCl}$, high redundancy and a low net production and $\mathrm{A} / \mathrm{C}$. Brouage Mudflat and Aiguillon Cove showed the same tendency as estuaries, with less extreme values than that of Narragansett Bay, Kromme or Swartkops estuaries.

The second principal component (that explained $20 \%$ of the variance) was positively correlated to the internal relative Ascendency (contribution: $28 \%$, dominating variable on this axis), and negatively correlated to the difference between total and internal relative Ascendency $(22 \%$, linked to the sensitivity to external exchanges) and to the production of quality (14\%). Brouage Mudflat and Aiguillon Cove were located at the extreme low values of this axis, with high quality production and high dependency to external exchanges.

[Figure 3]

\section{Discussion}

\subsection{Seasonal variations:}

According to our model, the Brouage Mudflat was characterized by a higher level of organization in winter than in summer. This would be linked to a higher redundancy of the flows in summer. This higher level of organization in winter implies a lower adaptation capacity (Heymans et al., 2002). This seasonal difference was not observed in Aiguillon Cove, but as this model presented more gaps in seasonal data, no conclusion will be drawn from it.

Comparing the Relative Ascendency and the internal Relative Ascendency quantifies the dependency on external factors. Indeed, the computation of internal Ascendency and development capacity does not consider the exchanges with the outside (Ulanowicz and Norden, 1990): hence, the gap between the two consists only of the internal Redundancy. The comparison between total and internal relative Ascendency represents a degree of dependency on the exogenous connections to adjacent ecological and physical systems (Baird et al., 1991). This difference remained constant during the two seasons, at both study sites, implying a constant dependency to external exchanges.

The drop in APL, $\mathrm{FCl}$, the number of cycles and their mean length suggest a diminution of stress for Brouage Mudflat during winter (Baird and Ulanowicz, 1989). The loss of one trophic level in Brouage Mudflat was associated with higher transfer efficiency between the two 
preceding ones, a lower trophic level of nekton juveniles but a higher one of grazing fish. Indeed, very different pathways occurred in summer and winter for Brouage Mudflat, whereas the diets of each compartment remained approximately the same in Aiguillon Cove.

The loss of one Trophic Level and increase of the Trophic Efficiency from level 2 to level 3 was due to the combined decrease in annelid efficiency and increase in nematode efficiency: there was a change in the carbon pathways in Brouage Mudflat, which does not occur in Aiguillon Cove. Indeed, as opposed to macrofauna, nematodes were more abundant in winter than in summer (Rzeznik-Orignac et al., 2003). The nematode dynamics have been studied in Brouage Mudflat (Rzeznik-Orignac et al., 2003), but not in Aiguillon Cove, and the sensitivity analyses showed that grazing by nematodes has a significant impact on the results (Degré et al., 2006): we can wonder if, with more information on this peculiar compartment, different patterns would be observed in Aiguillon Cove.

These observations underline the interest of coupling two seasons in the modelling of a food web, provided that enough information is available to characterize the seasonal patterns of the populations. The key role of nematodes is also shown in the food web dynamics. It had already been demonstrated that nematodes were an important compartment for benthic communities (Gerlach, 1971), at the detrital level (Escaravage et al., 1989), in the transfer of material towards higher trophic levels (Coull, 1990), and in food-web functioning (Leguerrier et al., 2003), but it is emphasized here that they may also play a structural role by forcing the trophic organization of the ecosystem. Schmid-Araya et al. (2002) suggested that meiofauna play a key role as intermediate between trophic levels, and adding this compartment in a conceptual model increased its complexity. Hence, meiofauna is an important compartment to consider in the choice of aggregation level in the conceptual model.

All these comparisons were done in tendency, without testing the significance of the observed differences. The lack of information on the variability of the numerous processes estimated, and on the biomass of some compartments, did not allow processing this statistical analysis (Bondavalli et al., 2006).

\subsection{Annual system properties}

Even though overall activity (TST) in Brouage Mudflat was 1.5 times higher than in Aiguillon Cove, the two mudflats showed similar global functioning, with net import from the ocean, net export of primary production, a predominance of benthic primary production over pelagic primary production due to its high turbidity (Blanchard and Cariou Le Gall, 1994), and dominating consumption of detritus. In parallel to a high benthic primary production, they both import material from the water column. To go further in this overall comparison, we will compare our two food-web results with those concerning other similarly modelled food webs.

\subsection{Advantages and limits of the inter-ecosystem comparison}

The use of network analysis for comparing ecosystem properties has been the subject of numerous articles bringing interesting ideas to coastal ecology. However, the dangers of such a comparison have also been highlighted. Early comparative studies using network analysis (Baird et al. 1991, 1993) emphasized that the degree of aggregation among the compartments had to be essentially the same in order to avoid artificial dissimilarities. Christensen (1995) has shown that several network indices were sensitive to the level of aggregation. This is why the selection made here was based of the number of compartments, and on the similarity in this level. Moreover, the comparison was only made on carbon-based or mass models translated into carbon. Models in phosphorus or nitrogen currency were not taken into account as they would involve processes specific to these currencies. However, some differences would remain between the compared models as shown in Appendix 1. Only Brouage and Aiguillon Cove had exactly the same structure. Others varied in the number of non-living compartments and micromeiofaunal living compartments. Both have been shown to be sensitive when using network analysis (microbial loop: Abarca-Arenas \& Ulanowicz 2002, non-living material: Allesina et al. 2005). This is why the comparison of the two systems Aiguillon Cove and Brouage with the other systems will be done considering tendencies and not exact values.

\subsection{Systems importing quantity but exporting quality}

Even though the two study sites import material, as opposed to most of the other systems (Table 4), the quality of imports is lower than that of exports. The quality of a unit of material is 
linked to the information embodied in its components. Marques et al. (1997) have followed the simplification proposed by Jørgensen et al. (1995) to compute Exergy: the simple multiplication of the compartment's biomass by a weighting factor using the detritus at the basic referencelevel gives, in arbitrary units, the quality embodied in the biomass considered. The yearly gains in quality were $304 \%$ and $123 \%$ of the yearly quality inputs for Aiguillon Cove and Brouage Mudflat, respectively, and each season had also a positive net quality production. Hence, the two systems were "producing quality" all over the year. Moreover, they were, amongst the most quality-productive systems (Table 4). The Kromme Estuary imports quality, all the others (when quality could be computed from the published results) export quality, but only the Peruvian upwelling exports more quality than Aiguillon Cove and Brouage Mudflat.

\subsection{Systems under low stress}

The $\mathrm{FCl}$ can be used for comparison purposes, even though it is subject to discussion (Allesina and Ulanowicz 2004) concerning its absolute value which may not include all flows involved in cycling. However, the new method they introduced (comprehensive cycling index, $\mathrm{CCl}$ ) appears to be linearly related to $\mathrm{FCl}$, in their analysis of 23 ecosystem models. As $\mathrm{CCl}$ is computationally intensive to determine, and appears as a linear multiple of $\mathrm{FCl}$, most of recent studies remain focused on $\mathrm{FCl}$ (e.g. Borrett and al., 2006).

Monaco and Ulanowicz (1997) associated high FCl and APL values with a high efficiency in retaining particulate matter within the food web. $\mathrm{FCl}$ has also been related to positive feedbacks in ecosystems that contribute to stability, and has been observed inversely correlated with system recovery time (Vasconcellos et al., 1997). According to Baird and Ulanowicz (1989), however, a paucity of cycles coupled with a high $\mathrm{FCl}$ index indicates a disturbed system. Baird et al. (1991) also associated a high $\mathrm{FCl}$ with a stressed system more than with a stable one. These findings may not be incompatible, and one could argue that stressed conditions could enhance rapid ecosystem adaptation. Here, even if the $\mathrm{FCl}$ was higher than in particular systems such as upwelling systems, they remain relatively low. The values of Brouage Mudflat and Aiguillon Cove are close to the mean $\mathrm{FCl}$ value of St Mark National Wildlife Refuge seagrass ecosystem (18\%: Baird et al., 1998) and of the Sylt-Rømø Bight ecosystem in the Wadden Sea (17\%: Baird et al. 2004). The low FCl of Brouage Mudflat and Aiguillon Cove associated with a great number of cycles, might reveal a poorly stressed system.

In Brouage Mudflat, the $\mathrm{FCl}$ is higher than in Aiguillon Cove. This is related to a more important shellfish culture. This could be interpreted as the fact that Brouage Mudflat, would be more stressed and adaptive than Aiguillon Cove.

The amount of overheads is also believed to indicate system resilience and strength in reserve (Heymans et al., 2002): low values of $\mathrm{A} / \mathrm{C}$ were observed for Brouage Mudflat and Aiguillon Cove. Both presented a high adaptation capacity.

\subsection{A large diversity of resources}

The detritivory/herbivory ratio of both Aiguillon Cove and Brouage Mudflat was within the range observed for estuaries and bays, being closest to that of Delaware and Chesapeake bays. Values of detritivory/herbivory were in the low part of this range in the models of St Mark (1.8; Baird et al., 1998) and Sylt-Rømø Bight (1.4; Baird et al, 2004). Relatively low for Aiguillon Cove, the $\mathrm{D} / \mathrm{H}$ ratio was higher in Brouage Mudflat, meaning that detritivory was an essential process there.

The efficiency of transfer of the primary production toward herbivores in Aiguillon Cove was higher than in Brouage Mudflat, and both of them were superior to the average observed for estuaries and bays and to values observed in the models of St Mark (46.6\%; Baird et al., 1998) and Sylt-Rømø Bight (57.5\%; Baird et al, 2004).

Hence, we can conclude that Brouage Mudflat and Aiguillon Cove benefit from a large diversity of resources in comparison to other systems. Indeed, it is known that those two mudflats receive material from different origins: river-borne detritus, neritic phytoplankton, microphytobenthos and "true" phytoplankton constitute a great variety of resources, used in the food web with efficiency (Riera, 1998; Guarini et al., 2004; Haubois et al., 2005).

Brouage Mudflat was, amongst all the compared ecosystems, the one that had the largest difference between total and internal Relative Ascendency values. Aiguillon Cove's indices showed also a large difference, comparable to that in the Seine Estuary. Hence, we can conclude that our two systems appeared to be very dependent on external conditions, with a higher dependence for Brouage Mudflat. 


\subsection{An intermediate maturity}

According to Christensen (1995), neither Maturity nor Stability can be defined consistently. Ulanowicz (1986), and then Baird et al. (1991) and Ulanowicz and Abarca-Arenas (1997) linked Maturity sensu Odum (1969) with Ascendency, observing that an increasing Ascendency was structurally linked to a higher species richness, more retention of resources within the system, and a tendency towards trophic specialization. Hence, in the absence of major perturbation, ecosystems should exhibit a propensity to increase their Ascendency. This has been discussed by Christensen (1995), as he found a negative correlation between Ascendency and Maturity. Perez-España and Arregun-Sanchez (1999) proposed an index of Maturity that they first linked to Stability and then, with dynamic simulations, found to be inversely correlated with stability (Perez-España and Arregun-Sanchez 2001). We will here evaluate the maturity of a system according to the coupled observation of net primary production / biomass (NPP/B) and gross primary production / system respiration (GPP/R) indices, following Odum's (1969) explanations in our interpretation.

The combined observations of NPP/B and GPP/R would suggest a more advanced maturity for Brouage Mudflat than for Aiguillon Cove, while the two systems should be, because they are under estuarine influence, relatively juvenile in comparison to other marine ecosystems (Frontier and Pichod-Viale, 1995).

The low APL and number of trophic levels could be partly due to the fact that the bacteria were merged with the detritus in a single compartment, whereas in most of the presented systems (Baird et al., 1991; Baird and Ulanowicz, 1993; Monaco and Ulanowicz, 1997; Sandberg et al., 2000), free pelagic bacteria are separated (Annexe 1). Indeed, the computation of the number of trophic levels for the Brouage Mudflat system in which bacteria were separated showed 5 trophic levels, and the Baird and Milne (1981) model of the Ythan estuary, which did not include separate bacterial compartment, showed 4 trophic levels. However, bacteria were not separately included by Rybarczyk and Elkaïm (2003) or Heymans et al. (2004), which present systems with at least 5 trophic levels. Moreover, the computation of the APL for Brouage Mudflat with bacterial compartments did not give a higher value (it was even lower: 1.63 was obtained). According to Valandro et al. (2003), the number of energy transformation levels in trophic webs is usually below 5 , but the number is greater in aquatic ecosystems. The transfer efficiencies are also very low for Aiguillon Cove and Brouage Mudflat in comparison to other systems values, which generally exceed $30 \%$ and can easily reach $70 \%$ for the first step.

Frontier and Pichod-Viale (1995) described the maturation of ecosystems in terms of gains in accumulated organic matter, in diversity of species and of ecological niches, in complexity, recycling, and organization, and proposed structural interpretation of rank-frequency diagrams. In Aiguillon Cove and Brouage Mudflat, such an interpretation of the rank-frequency diagrams of species showed a less mature system for Aiguillon Cove, as only 2 species, Scrobicularia plana and Hydrobia ulvae, dominate the populations, whereas the diagram is more equilibrated in Brouage Mudflat (Degré, unpublished results).

\section{Conclusion}

The network indices of the different ecosystems, synthesised by the principal component analysis, underlined the high similarity of functioning of Aiguillon Cove and Brouage Mudflat. Both presented general trends of most of the analysed estuaries (high redundancy, high recycling, low net production compared to the others) but these characteristics were less extreme than in most of the estuaries. Their only extreme position concerned their high quality production, and especially the export of living material: cultivated shellfish, grazing fish, and their dependency on external exchanges, linked to a high diversity of resources.

\section{Acknowledgements}

This work was supported by two grants from ONCFS on shorebirds and benthos interactions (D. Degré PhD grant), from ACl/ECCO (J.M. Guarini Program grant), and from the French Ministry of Agriculture - ENGREF (D. Leguerrier PhD grant). The authors thank Tammi Richardson, Anne-Gaëlle Haubois, Pierre-Guy Sauriau and Ian Jenkinson for English corrections and for useful comments. 


\section{References}

Abarca-Arenas, L.G., Ulanowicz, R.E., 2002. The effects of taxonomic aggregation on network analysis. Ecological Modelling 149, 285-296.

Allesina, S., Ulanowicz, R.E., 2004. Cycling in ecological networks: Finn's index revisited. Ecological Modelling 28, 227-233.

Allesina, S., Bondavalli, C., Scharler, U.M., 2005. The consequences of the aggregation of detritus pools in ecological networks. Ecological Modelling 189, 221-232.

Baird, D., McGlade, J.M., Ulanowicz, R.E., 1991. The comparative ecology of six marine ecosystems. Philosophical Transactions of the Royal Society of London. Series B. Biological Sciences 333, 15-29.

Baird, D., Milne, H., 1981. Energy flow in the Ythan Estuary, Aberdeenshire, Scotland. Estuarine Coastal and Shelf Science 13, 455-472.

Baird, D., Ulanowicz, R.E., 1989. The seasonal dynamics of the Chesapeake Bay ecosystem. Ecological Monographs 59, 329-364.

Baird, D., Ulanowicz, R.E., 1993. Comparative study on the trophic structure, cycling and ecosystem properties of four tidal estuaries. Marine Ecology Progress Series 99, 221237.

Baird, D., Luczkovich, J., Christian, R.R., (1998). Assessment of spatial and temporal variability in ecosystem attributes of the St Marks national wildlife refuge, Apalachee Bay, Florida. Estuarine, Coastal and Shelf Science 47, 329-349.

Baird, D., Asmus, H., Asmus, R., 2004. Energy flow of a boreal intertidal ecosystem, the SyltRømø Bight. Marine Ecology Progress Series 279, 45-61.

Bassoullet, P., Le Hir, P., Gouleau, D., Robert, S., 2000. Sediment transport over an intertidal mudflat: field investigations and estimation of fluxes within the "Baie de MarennesOléron" (France). Continental Shelf Research 20, 1635-1653.

Bastianoni, S., Marchettini, N., 1997. Emergy/exergy ratio as a measure of the level of organization of systems. Ecological Modelling 99, 33-40.

Bendoricchio, G., Jørgensen, S.E., 1997. Exergy as goal function of ecosystems dynamic. Ecological Modelling 102, 5-15.

Blanchard, G.F., Cariou-Le Gall, V., 1994. Photosynthetic characteristics of microphytobethos in Marennes-Oléron Bay, France: preliminary results. Journal of Experimental Marine Biology and Ecology 182, 1-14.

Bondavalli, C., Bodini, A., Rossetti, G., Allesina, S., 2006. Detecting stress at the wholeecosystem level: The case of a mountain lake (Lake Santo, Italy). Ecosystems 9, 768787.

Borrett, S.R., Whipple, S.J., Patten, B.C., Christian, R.R. 2006. Indirect effects and distributed control in ecosystems. Temporal variability of indirect effects in a seven-compartment model of nitrogen flow in the Neuse River Estuary (USA): time series analysis. Ecological Modelling 194, 178-188.

Borrett, S.R., Osidele, O.O., 2007. Environ indicator sensitivity to flux uncertainty in a phosphorus model of Lake Sidney Lanier, USA. Ecological Modelling 200, 371-383.

Christensen, V., Pauly, D., 1992. ECOPATH II - a software for balancing steady-state ecosystem models and calculating network characteristics. Ecological Modelling, 61, 169-185.

Christensen, V., 1995. Ecosystem maturity - towards quantification. Ecological Modelling 77, 332.

Coull, B.C., 1990. Are members of the meiofauna food for higher trophic levels? Transactions of the American Microscopical Society 109, 233-246.

Degré, D., Leguerrier, D., Armynot du Chatelet, E., Rzeznik, J., Auguet, J.-C., Dupuy, C., Marquis, E., Fichet, D., Struski, C., Joyeux, E., Sauriau, P.-G., Niquil, N., 2006. Comparative analysis of the food webs of two intertidal mudflats during two seasons using inverse modelling: Aiguillon Cove and Brouage Mudflat, France. Estuarine, Coastal and Shelf Science, 69, 107-124.

Escaravage, V., Garcia, M.E., Castel, J., 1989. The distribution of meiofauna and its contribution to detritic pathways in tidal flats (Arcachon Bay, France). Topics in marine biology. Ros J.D. (ed) 53, 551-559.

Fath, B.D., 2004. Distributed control in ecological networks. Ecological Modelling 179, 235-245.

Fath, B.D., Jørgensen, S.E., Patten, B.C., Straškraba, M., 2004. Ecosystem growth and development. BioSystems 77, 213-228.

Fath, B.D., Patten, B.C., 1998. Network synergism: Emergence of positive relations in ecological systems. Ecological Modelling 107, 127-143. 
Fath, B.D., Patten, B.C., 1999. Quantifying resource homogenisation using network flow analysis. Ecological Modelling 123, 193-205.

Fath, B.D., Patten, B.C., Choi, J.S., 2001. Complementarity of Ecological Goal Functions. Journal of Theoretical Biology 208, 493-506.

Finn, J.T., 1976. Measures of ecosystem structure and function derived from analysis of flows. Journal of Theoretical Biology 56, 363-380.

Frontier, S., Pichod-Viale, D., 1995. Ecosystèmes. Structure, Fonctionnement, Evolution. Masson, Paris, $447 \mathrm{pp}$.

Gerlach, S.A., 1971. On the importance of meiofauna for benthos communities. Oecologia 6, 176-190.

Gouleau, D., Jouanneau, J.M., Weber, O., Sauriau, P.G., 2000. Short- and long-term sedimentation on Montportail-Brouage intertidal mudflat, Marennes-Oléron Bay, France. Continental Shelf Research 20, 1513-1530.

Goulletquer, P., Héral, M., 1997. Marine molluscan production trends in France: from fisheries to aquaculture. In: MacKensie, C.L., Bunell, V.G., Rosenfield, A. (Eds.), The history, present condition, and future of the Molluscan fishereis of North America and Europe. NOAA Technical Report NMFS 129, Department of Commerce, Seattle, Washington, pp. 137-164.

Goulletquer, P., Le Moine, O., 2002. Shellfish farming and Coastal Zone Management (CZM) development in Marennes-Oléron Bay and Charentais Sounds (Charente-Maritime, France): A review of recent developments. Aquaculture International 10, 507-525.

Guarini, J.-M., Gros, P., Blanchard, G., Richard, P., Fillon, A., 2004. Benthic contribution to pelagic microalgal communities in two semi-enclosed, European-type littoral ecosystems (Marennes-Oléron Bay and Aiguillon Bay, France). Journal of Sea Research 52, 241-258.

Haubois, A.-G., Guarini, J.-M., Richard, P., Hemon, A., Arotcharen, E., Blanchard, G.F., 2004. Differences in spatial structures between juveniles and adults of the gastropod Hydrobia ulvae on an intertidal mudflat (Marennes-Oléron Bay, France) potentially affect estimates of local demographic processes. Journal of Sea Research 51, 63-68.

Haubois, A.-G., Guarini, J.-M., Richard, P., Fichet, D., Radenac, G., Blanchard, G.F., 2005. Ingestion rate of the deposit-feeder Hydrobia ulvae (Gastropoda) on epipelic diatoms: effect of cell size and angal biomass. Journal of Experimental Marine Biology and Ecology 317, 1-12.

Heymans, J.J., Shannon, L.J., Jarre, A., 2004. Changes in the northern Benguela ecosystem over three decades: 1970s, 1980s and 1990s. Ecological Modelling 172, 175-195.

Heymans, J.J., Ulanowicz, R.E., Bondavalli, C., 2002. Network analysis of the South Florida Everglades graminoid marshes and comparison with nearby cypress ecosystems. Ecological Modelling 149, 5-23.

Higashi, M., Patten, B.C., Burns, T.P., 1993. Network trophic dynamics: the modes of energy utilization in ecosystems. Ecological Modelling 66, 1-42.

Jørgensen, S.E., 1999. State-of-the-art of ecological modelling with emphasis on development of structural dynamic model. Ecological Modelling 120, 75-96.

Jørgensen, S.E., Müller, F., 2000a. Towards a unifying theory. In: Jørgensen, S.E., Müller, F. (Eds.) Handbook of ecosystem theories and management. Lewis Publisher, CRC Press LLC, pp. 465-471.

Jørgensen, S.E., Müller, F., 2000b. Ecosystems as complex systems. In: Jørgensen, S.E., Müller, F. (Eds.) Handbook of ecosystem theories and management. CRC Press LLC, pp. 5-20.

Jørgensen, S.E., Nielsen, S.N., Mejer, H., 1995. Emergy, environ, exergy and ecological modelling. Ecological Modelling 77, 99-109.

Kay, J., Graham, L.A., Ulanowicz, R.E., 1989. A detailed guide for network analysis. In: Wulff, F., Field, J.G., Mann, K.H. (Eds.) Network analysis in marine ecology. Methods and applications. Springer-Verlag, Berlin, pp. 15-61.

Le Hir, P., Roberts, W., Cazaillet, O., Christie, M., Bassoulet, P., Bacher, C., 2000. Characterization of intertidal flat hydrodynamics. Continental Shelf Research 20, 14331459.

Le Pape, O., Holley, J., Guérault, D., Désaunay, Y., 2003. Quality of coastal and estuarine essential fish habitats: estimations based on the size of juvenile common sole (Solea solea L.). Estuarine, Coastal and Shelf Science 58, 793-803.

Leguerrier, D., Niquil, N., Boileau, N., Rzeznik, J., Sauriau, P.-G., Le Moine, O., Bacher, C., 2003. Numerical analysis of the food web of an intertidal mudflat ecosystem on the Atlantic coast of France. Marine Ecology Progress Series 246, 17-37.

Leguerrier, D., Niquil, N., Petiau, A., Bodoy, A., 2004. Modeling the impact of oyster culture on 
a mudflat food web in Marennes-Oléron Bay (France). Marine Ecology Progress Series 273, 147-162.

Marques, J.C., Pardal, M.A., Nielsen, S.N., Jørgensen, S.E., 1997. Analysis of the properties of exergy and biodiversity along an estuarine gradient of eutrophication. Ecological Modelling 102, 155-167.

McLusky, D.S., Elliott, M., 2004. The Estuarine Ecosystem: ecology, threats and management. OUP, Oxford, pp. 214.

Monaco, M.E., Ulanowicz, R.E., 1997. Comparative ecosystem trophic structure of three US mid-Atlantic estuaries. Marine Ecology Progress Series 161, 239-254.

Odum, E.P., 1969. The strategy of ecosystem development. Science 164, 732-731.

Odum, H.T., 1988. Self-organization, transformity and information. Science 242, 1132-1139.

Odum, H.T., Pinkerton, R.C., 1955. Time's speed regulator. American Scientist 43, 321-343.

Ortiz, M., Wolff, M., 2002. Trophic model of four benthic communities in Tongoy Bay (Chile): comparative analysis and preliminary assessment of management strategies. Journal of Experimental Marine Biology and Ecology 268, 205-235.

Patten, B.C., 1995 Network integration of ecological extremal principles: exergy, emergy, power, ascendency, and indirect effects. Ecological Modelling 79, 75-84

Pérez-España, H., Arregùn-Sanchez, F., 1999. A measure of ecosystem maturity. Ecological Modelling 119, 79-85.

Riera, P., 1998. d15N of organic matter sources and benthic invertebrates along an estuarine gradient in Marennes-Ole'ron Bay (France): implications for the study of trophic structure. Marine Ecology Progress Series 166, 143-50.

Rybarczyk, H., Ellkaïm, B., 2003. An analysis of the trophic network of a macrotidal estuary: the Seine Estuary (Eastern Channel, Normandy, France). Estuarine, Coastal and Shelf Science 58, 775-791.

Rzeznik-Orignac, J., Fichet, D., Boucher, G., 2003. Spatio-temporal structure of the nematode assemblages of the Brouage mudflat (Marennes-Oléron Bay, France). Estuarine, Coastal and Shelf Science 58, 77-88.

Sandberg, J., Elmgren, R., Wulff F., 2000. Carbon flows in Baltic Sea food webs - a reevaluation using a mass-balance approach. Journal of Marine Systems 25, 249-260.

Schmid-Araya, J.M., Hildrew, A.G., Robertson, A., Schmid, P.E., Winterbottom, J., 2002. The importance of meiofauna in food webs: evidence from an acid stream. Ecology 83, 1271-1285.

Schneider, E.D., Kay, J.J., 1994. Manifestation of the second law of thermodynamics. Mathematical and Computer Modelling 19, 25-48.

SHOM, 2001. Courants de marée de la côte ouest de France de Saint-Nazaire à Royan. Servie Hydrographique et Océanographique de la Marine (Ed.), Brest, 72 pp.

Szyrmer, J., Ulanowicz, R.E., 1987. Total flows in ecosystems. Ecological Modelling 35, 123136.

Triplet, P., Le Dréan-Quénec'hdu, S., Mahéo, R., 2001. Incidence des infrastructures portuaires et des activités humaines sur l'abondance et la répartition des limicoles sur le littoral français. In: Drévès, L., Chaussepied, M. (Eds.), Restauration des écosystèmes côtiers. Ifremer, Brest, pp. 243-255.

Ulanowicz, R.E., 1986. Growth and development: ecosystem phenomenology. Springer-Verlag, New York, 203 pp.

Ulanowicz, R.E., 1997. Ecology, the ascendant perspective. Columbia University Press, NY, $201 \mathrm{pp}$.

Ulanowicz, R.E., 1999. NETWRK 4.2 a package of computer algorithms to analyse ecological flow networks. http://www.cbl.umces.edu/ ulan/ntwk/network.html

Ulanowicz, R.E., Abarca-Arenas, L.G., 1997. An informational synthesis of ecosystem structure and function. Ecological Modelling 95, 1-10.

Ulanowicz, R.E., Norden, J.S., 1990. Symmetrical overheads in flow networks. Int J Systems Sci 21, 429-437.

Valandro, L., Caimmi, R., Colombo, L., 2003. What is hidden behind the concept of ecosystem efficiency in energy transformation? Ecological Modelling 170, 185-191.

Vasconcellos, M., Mackinson, S., Sloman, K., Pauly, D., 1997. The stability of trophic massbalance model of marine ecosystems: A comparative analysis. Ecological Modelling $100,125-134$.

Verger, F., 1968. Marais et wadden du littoral français. Biscaye frères, Bordeaux, $541 \mathrm{pp}$.

Vézina, A.F., 1989. Construction of flow networks using inverse methods. In: Wulff, F., Field, J.G., Mann, K.H. (Eds.), Network analysis in marine ecology. Methods and applications. Springer-Verlag, Berlin.

Vézina, A.F., Platt, T., 1988. Food web dynamics in the ocean. I. Best estimates using inverse 
methods. Marine Ecology Progress Series 42, 269-287.

Winemiller, K.O., Polis, G.A., 1996. Food webs: what do they tell us about the world? In: Polis, G.A., Winemiller, K.O. (Eds.), Food webs. Integration of patterns and dynamics. Chapman and Hall, New York, pp. 1-22. 
Table 1: Description of the sites of the inter-system comparison and bibliographic references: 1- Baird et al. 1991, 2- Ortiz and Wolff 2002, 3- Heymans et al. 2004, 4- Baird and Ulanowicz 1993, 5- Rybarczyk and Elkaïm 2003, 6- Monaco and Ulanowicz 1997, 7- Sandberg et al. 2000, 8- Baird and Milne 1981, 9- Degré et al. 2006. When a reference is cited by new authors, the new reference is after (exponent into brackets) the original one.

\begin{tabular}{|c|c|c|c|c|c|c|}
\hline ref & site & lat - long & ocean or sea & localisation & dimension & description \\
\hline 1 & Peruvian upwelling & $\begin{array}{c}4^{\circ} \mathrm{S}-81^{\circ} \mathrm{W} \\
14^{\circ} \mathrm{S}-77^{\circ} \mathrm{W}\end{array}$ & Pacific & Peru & $\begin{array}{l}2100 \mathrm{~km} \text { long - } \\
370 \mathrm{~km} \text { wide }\end{array}$ & upwelling system \\
\hline 2 & Tongoy Bay & $\begin{array}{l}30^{\circ} 15^{\prime} \mathrm{S}- \\
71^{\circ} 31^{\prime} \mathrm{W}\end{array}$ & Pacific & Coquimbo, Chile & $\begin{array}{l}16 \text { km long, } \\
\text { including } 2 \mathrm{~km} \\
\text { in Puerto Aldea }\end{array}$ & $\begin{array}{l}\text { Seagrass medows (0-4 m depth) } \\
\text { Sand-gravel (4-10 m depth) } \\
\text { sand (10-14 m depth) } \\
\text { mud ( }>14 \text { m depth) } \\
\text { total }\end{array}$ \\
\hline 1 & & & & & & Southern System (500 m depth) \\
\hline 3 & Benguela upwelling & $\begin{array}{l}15^{\circ} \mathrm{S}-5^{\circ} \mathrm{E} \\
27^{\circ} \mathrm{S}-15^{\circ} \mathrm{E}\end{array}$ & $\begin{array}{l}\text { South-Eastern } \\
\text { Atlantic }\end{array}$ & $\begin{array}{l}\text { Namibia - } \\
\text { Southern Africa }\end{array}$ & $179000 \mathrm{~km}^{2}$ & $\begin{array}{l}\text { Northern System ; 70s } \\
\text { Northern System ; 80s } \\
\text { Northern System ; 90s }\end{array}$ \\
\hline $1^{(4,5)}$ & Swartkops estuary & $\begin{array}{l}32^{\circ} 52^{\prime} \mathrm{S}- \\
25^{\circ} 39^{\prime} \mathrm{E}\end{array}$ & Indian & $\begin{array}{l}\text { southeast of } \\
\text { Southern Africa }\end{array}$ & $\begin{array}{l}15 \mathrm{~km} \text { long } \\
4 \mathrm{~km}^{2}\end{array}$ & $\begin{array}{l}\text { salt marshes and sand flats, shallow, } \\
\text { temperate, turbid, salinity gradient ( } 10 \text { - } \\
\text { 35), sediment gradient (fine grained sand } \\
\text { and mud - coarse sand) }\end{array}$ \\
\hline 4 & Kromme estuary & $\begin{array}{l}34^{\circ} 08^{\prime} \mathrm{S}- \\
24^{\circ} 51^{\prime} \mathrm{E}\end{array}$ & Indian & $\begin{array}{l}\text { southeast of } \\
\text { Southern Africa }\end{array}$ & $\begin{array}{l}14 \mathrm{~km} \text { long } \\
3 \mathrm{~km}^{2}\end{array}$ & $\begin{array}{l}\text { salt marshes and sand flats, shallow, well- } \\
\text { mixed and temperate, salinity gradient } \\
\text { (bellow 32), sediment gradient (organic } \\
\text { rich mud - sand) }\end{array}$ \\
\hline $6^{(5)}$ & Narragansett Bay & $\begin{array}{l}41^{\circ} 35^{\prime} \mathrm{N}- \\
71^{\circ} 22^{\prime} \mathrm{W}\end{array}$ & $\begin{array}{l}\text { North- } \\
\text { Western } \\
\text { Atlantic }\end{array}$ & $\begin{array}{l}\text { West and East } \\
\text { Passages, } \\
\text { Sakonnet River, } \\
\text { USA }\end{array}$ & $\begin{array}{l}48 \mathrm{~km} \text { long - } 4.8 \\
\text { to } 19 \mathrm{~km} \text { wide }\end{array}$ & $\begin{array}{l}\text { anthropogenically stressed, } 30 \text { to } 32 \text { of } \\
\text { salinity }\end{array}$ \\
\hline $6^{(5)}$ & Delaware Bay & $\begin{array}{l}39^{\circ} 02^{\prime} \mathrm{N}- \\
75^{\circ} 06^{\prime} \mathrm{W}\end{array}$ & $\begin{array}{l}\text { North- } \\
\text { Western } \\
\text { Atlantic }\end{array}$ & $\begin{array}{l}\text { Cape May - Cape } \\
\text { Henlopen, } \\
\text { Schuylkill River, } \\
\text { USA }\end{array}$ & $84 \mathrm{~km}$ long & $\begin{array}{c}\text { anthropogenically stressed, } 0 \text { to } 35 \text { of } \\
\text { salinity }\end{array}$ \\
\hline $\begin{array}{c}6^{(5)} \\
1\end{array}$ & Chesapeake Bay & $\begin{array}{l}36^{\circ} 50^{\prime} \text { to } \\
39^{\circ} 40^{\prime} \mathrm{N}- \\
76^{\circ} 10^{\prime} \mathrm{W}\end{array}$ & $\begin{array}{l}\text { North- } \\
\text { Western } \\
\text { Atlantic }\end{array}$ & $\begin{array}{c}\text { Susquehanna and } \\
\text { Potomac Rivers, } \\
\text { USA }\end{array}$ & $\begin{array}{l}320 \mathrm{~km} \text { long - } \\
4.8 \text { to } 48 \mathrm{~km} \\
\text { wide }\end{array}$ & $\begin{array}{l}\text { mesohaline region (salinity from } 6 \text { to } 18 \text { ), } \\
\text { pollutants and nutrients in runoff }\end{array}$ \\
\hline 7 & Bothnian Bay & $\begin{array}{l}65^{\circ} \mathrm{N}- \\
23^{\circ} \mathrm{E}\end{array}$ & \multicolumn{2}{|c|}{ Northern Bay in the Balthic Sea } & $36000 \mathrm{~km}^{2}$ & low saline and oligotrophic \\
\hline 7 & Bothnian Sea & $\begin{array}{l}62^{\circ} \mathrm{N}- \\
19^{\circ} \mathrm{E}\end{array}$ & \multicolumn{2}{|c|}{ Middle Bay in the Balthic Sea } & $79000 \mathrm{~km}^{2}$ & mesohaline, non tidal estuary \\
\hline $\begin{array}{l}7 \\
1 \\
\end{array}$ & Baltic proper & $\begin{array}{l}56^{\circ} \mathrm{N}- \\
19^{\circ} \mathrm{E} \\
\end{array}$ & \multicolumn{2}{|c|}{ Southern Bay in the Balthic Sea } & $210000 \mathrm{~km}^{2}$ & higher levels of salinity and nutrient \\
\hline 4 & Ythan Estuary & $\begin{array}{l}57^{\circ} 20^{\prime} \mathrm{N}- \\
2^{\circ} 00^{\prime} \mathrm{W}\end{array}$ & North Sea & $\begin{array}{l}\text { Aberdeen, } \\
\text { Scotland }\end{array}$ & $\begin{array}{l}71 \text { ha subtidal + } \\
185 \text { ha intertidal } \\
\text { areas }\end{array}$ & $\begin{array}{l}\text { salinity gradient (0-35), sediment gradient } \\
\text { (mud and mud-sand, sand, mussels beds, } \\
\text { and stones), } 2000 \mathrm{~m}^{3} \cdot \mathrm{d}^{-1} \text { primary treated } \\
\text { sewage }\end{array}$ \\
\hline $1^{(4)}$ & Ems Estuary & $\begin{array}{l}53^{\circ} 26^{\prime} \mathrm{N}- \\
6^{\circ} 54^{\prime} \mathrm{E}\end{array}$ & Wadden Sea & Netherlands & $500 \mathrm{~km}^{2}$ & $\begin{array}{l}\text { shallow semi-diurnal tidal estuary, } \\
\text { shallow, large tidal flats, salinity (14 - 34), } \\
\text { large amounts of nutrients, little } \\
\text { eutrophication or pollution }\end{array}$ \\
\hline 5 & Seine Estuary & $\begin{array}{c}49^{\circ} 25^{\prime} \mathrm{N}- \\
00^{\circ} 14^{\prime} \mathrm{E} \\
\end{array}$ & $\begin{array}{c}\text { Eastern } \\
\text { Channel } \\
\end{array}$ & $\begin{array}{c}\text { River Seine, } \\
\text { Honfleur, France }\end{array}$ & $\begin{array}{l}106 \mathrm{~km} \text { long - } \\
34.34 \mathrm{~km} \text { wide }\end{array}$ & $\begin{array}{l}\text { poly- or mesohaline mudflats }(10-25) \text {, } \\
\text { meso- or oligohaline upstream }(0.5-10)\end{array}$ \\
\hline 9 & Aiguillon Cove & $\begin{array}{l}46^{\circ} 15^{\prime} \mathrm{N}- \\
1^{\circ} 10^{\prime} \mathrm{W}\end{array}$ & $\begin{array}{l}\text { North-Eastern } \\
\text { Atlantic }\end{array}$ & $\begin{array}{l}\text { Breton Sound, } \\
\text { Sèvre Niortaise } \\
\text { river, France }\end{array}$ & $\begin{array}{l}3.5 \mathrm{~km} \text { wide in } \\
\text { Charente- } \\
\text { Maritime, } 3 \mathrm{~km} \\
\text { wide in Vendée }\end{array}$ & $\begin{array}{l}\text { semi-enclosed macrotidal bay, extended } \\
\text { mudflats, estuarine influence, } \\
\text { neighbouring salt-marshes }\end{array}$ \\
\hline 9 & Brouage Mudflat & $\begin{array}{l}45^{\circ} 55^{\prime} \mathrm{N}- \\
1^{\circ} 08^{\prime} \mathrm{W}\end{array}$ & $\begin{array}{l}\text { North-Eastern } \\
\text { Atlantic }\end{array}$ & $\begin{array}{l}\text { Marennes-Oléron } \\
\text { Bay, Charente } \\
\text { river, France }\end{array}$ & $4.5 \mathrm{~km}$ wide & $\begin{array}{l}\text { eastern extended mudflat, estuarine } \\
\text { influence, 'ridges and runnels' bedforms }\end{array}$ \\
\hline
\end{tabular}


Table 2: Network analysis indices. TST $=$ Total System Throughput. NSP $=$ Net System Production $\left(\mathrm{gC} \cdot \mathrm{m}^{-2} \cdot \mathrm{y}^{-1}\right)$, NSQP $=$ Net System Quality Production, $\mathrm{N}(\mathrm{TL})=$ number of trophic levels, $\operatorname{TE}(1 \rightarrow 2)=$ Trophic Efficiency from trophic level 1 to level 2 (calculated from the Lindeman Spine aggregation into a linear chain), $\operatorname{TE}(2 \rightarrow 3)=$ idem for level 2 to $3, \operatorname{TE}(3 \rightarrow 4)=$ idem from level 3 to $4, \mathrm{D} / \mathrm{H}=$ detritivory/herbivory, $\mathrm{APL}=$ Average Path Length, $\mathrm{FCl}=$ Finn Cycling Index, $\mathrm{N}$ cycles = Number of cycles, $<$ Length $>=$ mean length of cycles, $\mathrm{A}=$ Ascendancy, $\mathrm{C}=$ Development Capacity, $\mathrm{A} / \mathrm{C}=$ Relative Ascendency (Ascendency/Development Capacity), R/C = Relative Redundancy, $\mathrm{Ai} / \mathrm{Ci}=$ internal Relative Ascendency (internal Ascendency/internal Development Capacity), Dimensional indices are given in $\mathrm{gC} \cdot \mathrm{m}^{-2} \cdot$ month $^{-1}$ for the seasonal models and in $\mathrm{gC} \cdot \mathrm{m}^{-2} \cdot \mathrm{y}^{-1}$ for the year models.

\begin{tabular}{|c|c|c|c|c|c|c|}
\hline & $\begin{array}{c}A C \\
\text { summer }\end{array}$ & $\begin{array}{c}\mathrm{AC} \\
\text { winter }\end{array}$ & $\begin{array}{c}\text { BM } \\
\text { summer }\end{array}$ & $\begin{array}{c}\mathrm{BM} \\
\text { winter }\end{array}$ & $\begin{array}{c}\mathrm{AC} \\
\text { annual }\end{array}$ & $\begin{array}{c}\text { BM } \\
\text { annual }\end{array}$ \\
\hline & \multicolumn{4}{|c|}{ gC. $\mathrm{m}^{-2} \cdot$ month $^{-1}$} & \multicolumn{2}{|c|}{$g C \cdot m^{-2} \cdot y^{-1}$} \\
\hline TST & 751 & 607 & 1026 & 1139 & 8295 & 12874 \\
\hline NSP & -64 & -45 & -24 & -19 & -673 & -263 \\
\hline NSQP & 2481 & 2040 & 384 & 2150 & 27562 & 12734 \\
\hline NTL & 4 & 4 & 4 & 3 & 4 & 4 \\
\hline $\mathrm{TE}(1 \rightarrow 2)$ & $28.50 \%$ & $24.30 \%$ & $16.50 \%$ & $15.80 \%$ & $27 \%$ & $16.20 \%$ \\
\hline $\mathrm{TE}(2 \rightarrow 3)$ & $5.69 \%$ & $6.32 \%$ & $4.47 \%$ & $7.02 \%$ & $5.89 \%$ & $5.60 \%$ \\
\hline $\mathrm{TE}(3 \rightarrow 4)$ & $0.04 \%$ & $0.11 \%$ & $4.54 \%$ & 0 & $0.06 \%$ & $2.30 \%$ \\
\hline D/H & 4.77 & 5.01 & 5.98 & 7.50 & 4.85 & 6.55 \\
\hline APL & 1.89 & 1.96 & 1.82 & 1.62 & 1.92 & 1.73 \\
\hline $\mathrm{FCl}$ & $13.6 \%$ & $14.1 \%$ & $23.0 \%$ & $11.3 \%$ & $14.9 \%$ & $19.2 \%$ \\
\hline $\mathrm{N}$ cycles & 25 & 24 & 44 & 31 & 26 & 48 \\
\hline <Length> & 2.68 & 2.55 & 3.5 & 2.93 & 2.65 & 3.46 \\
\hline A & 1015 & 803 & 1308 & 1578 & 10878 & 16615 \\
\hline C & 3199 & 2631 & 3949 & 3952 & 35847 & 48301 \\
\hline$R / C$ & $32.6 \%$ & $33.5 \%$ & $37.6 \%$ & $31.4 \%$ & $33.5 \%$ & $36.1 \%$ \\
\hline$A / C$ & $31.7 \%$ & $30.5 \%$ & $33.1 \%$ & $39.9 \%$ & $30.3 \%$ & $34.4 \%$ \\
\hline $\mathrm{Ai} / \mathrm{Ci}$ & $20.4 \%$ & $19.2 \%$ & $15.3 \%$ & $22.2 \%$ & $18.7 \%$ & $16.3 \%$ \\
\hline $\mathrm{A} / \mathrm{C}-\mathrm{A} \mathrm{i} / \mathrm{Ci}$ & $11.3 \%$ & $11.3 \%$ & $17.8 \%$ & $17.7 \%$ & $11.6 \%$ & $18.1 \%$ \\
\hline
\end{tabular}


Table 3: Comparison of indices of Network Analysis for various ecosystems (same bibliographic and food web references than in the table 1). The indices presented are the following ones: Net System Production (NSP: $\mathrm{gC} \cdot \mathrm{m}^{-2} \cdot \mathrm{y}^{-1}$ ), Net System Quality Production (NSQP: energy unit), Average Path Length $(\mathrm{APL})$ and Number of trophic levels $\left(\mathrm{N}_{(\mathrm{TL})}\right)$, Total Finn Cycling Index $(\mathrm{FCl})$, fluxes to Detritus / Total System Throughput (FtoD/TST), detritivory/herbivory (D/H), Relative Ascendancy (Ascendency/Development Capacity: A/C), Redundancy normalized by the Development Capacity $(R / C)$, internal relative ascendancy (Ascendancy/internal Development: $A_{i} / C_{i}$ ), Primary Production Efficiency (PPeff: net primary production / herbivory), Net Primary Production / total Biomass (without detritus) (NPP/B), Gross Primary Production / total System Respiration (GPP/R), Net Primary Production / non-primary producers Respiration (NPP/R). When the computation was possible, values not given in the cited articles have been computed (values in italics), when it was not possible, the corresponding cells are left blank. Coloured cells correspond to values that are superior to the mean data for the studied systems.

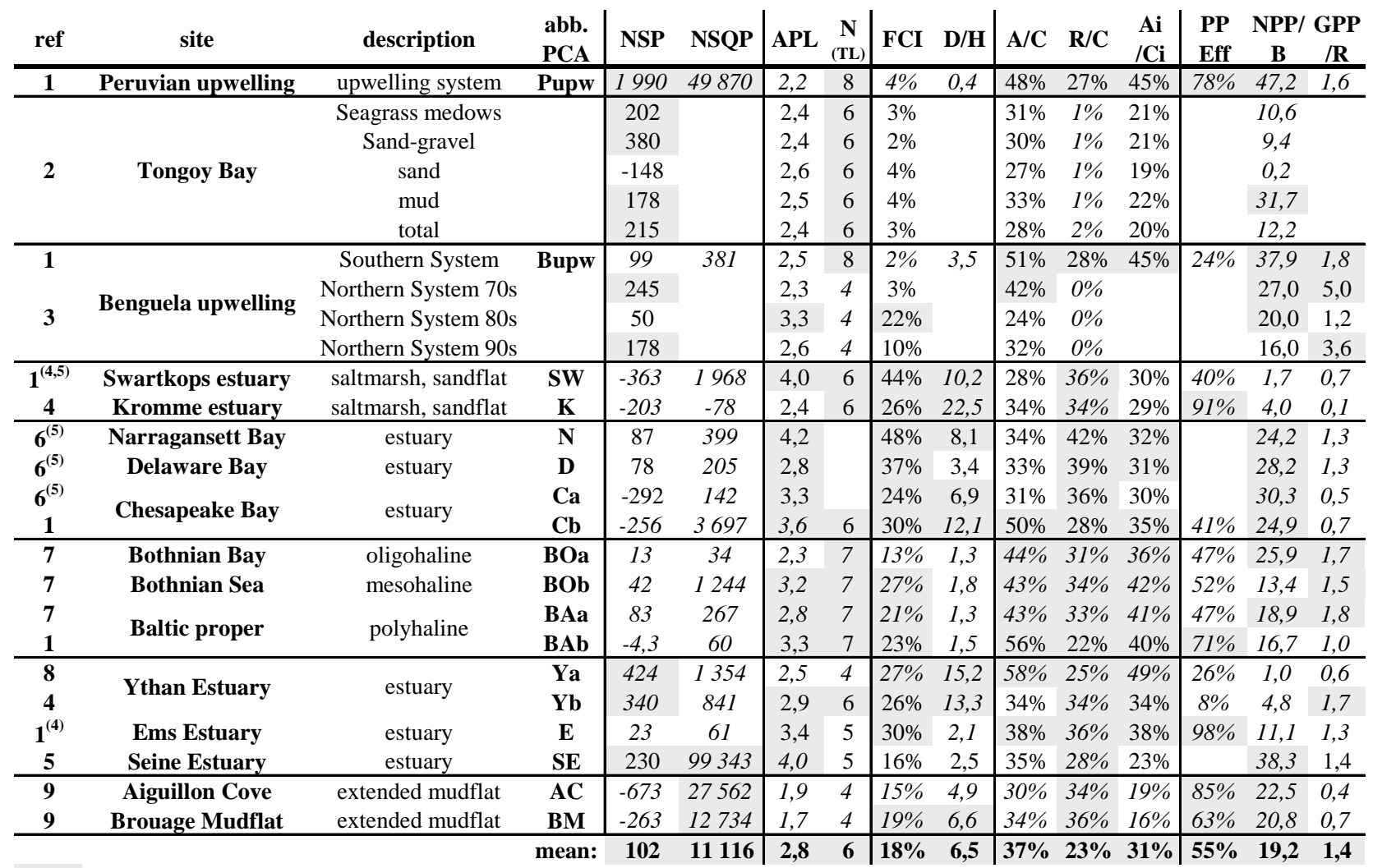

values superior to the mean 


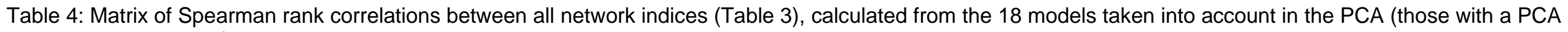
abbreviation in Table 3).

\begin{tabular}{|c|c|c|c|c|c|c|c|c|c|c|c|}
\hline & NSP & NSQP & APL & $\mathrm{FCl}$ & $\mathrm{D} / \mathrm{H}$ & $A / C$ & $\mathrm{R} / \mathrm{C}$ & $\mathrm{Ai} / \mathrm{Ci}$ & NPP/B & GPP/R & $\mathrm{A} / \mathrm{C}-\mathrm{Ai} / \mathrm{Ci}$ \\
\hline NSP & 1 & 0.146 & 0.015 & -0.133 & -0.183 & 0.497 & -0.356 & 0.606 & 0.172 & 0.608 & -0.145 \\
\hline NSQP & & 1 & -0.024 & -0.166 & 0.063 & -0.045 & -0.227 & -0.139 & 0.220 & -0.047 & 0.217 \\
\hline APL & & & 1 & 0.606 & 0.152 & -0.147 & 0.215 & -0.051 & -0.026 & 0.069 & -0.392 \\
\hline $\mathrm{FCl}$ & & & & 1 & 0.482 & -0.317 & 0.562 & -0.082 & -0.517 & -0.318 & -0.456 \\
\hline $\mathrm{D} / \mathrm{H}$ & & & & & 1 & -0.306 & 0.274 & -0.356 & -0.472 & -0.607 & -0.062 \\
\hline $\mathrm{A} / \mathrm{C}$ & & & & & & 1 & -0.780 & 0.786 & 0.054 & 0.374 & 0.402 \\
\hline $\mathrm{R} / \mathrm{C}$ & & & & & & & 1 & -0.541 & -0.132 & -0.222 & -0.500 \\
\hline $\mathrm{Ai} / \mathrm{Ci}$ & & & & & & & & 1 & -0.057 & 0.534 & -0.151 \\
\hline NPP/B & & & & & & & & & 1 & 0.303 & 0.271 \\
\hline GPP/R & & & & & & & & & & 1 & -0.294 \\
\hline $\mathrm{A} / \mathrm{C}-\mathrm{Ai} / \mathrm{Ci}$ & & & & & & & & & & & 1 \\
\hline
\end{tabular}

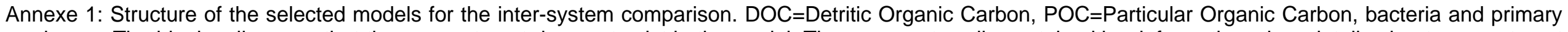

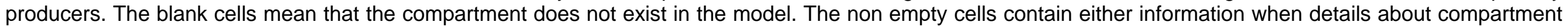

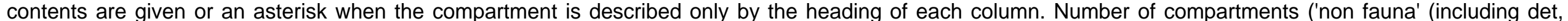

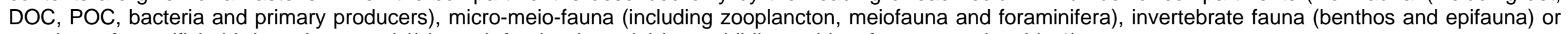
vertebrate fauna (fish, birds and mammals)) in each food web model (same bibliographic references as in table 1). 


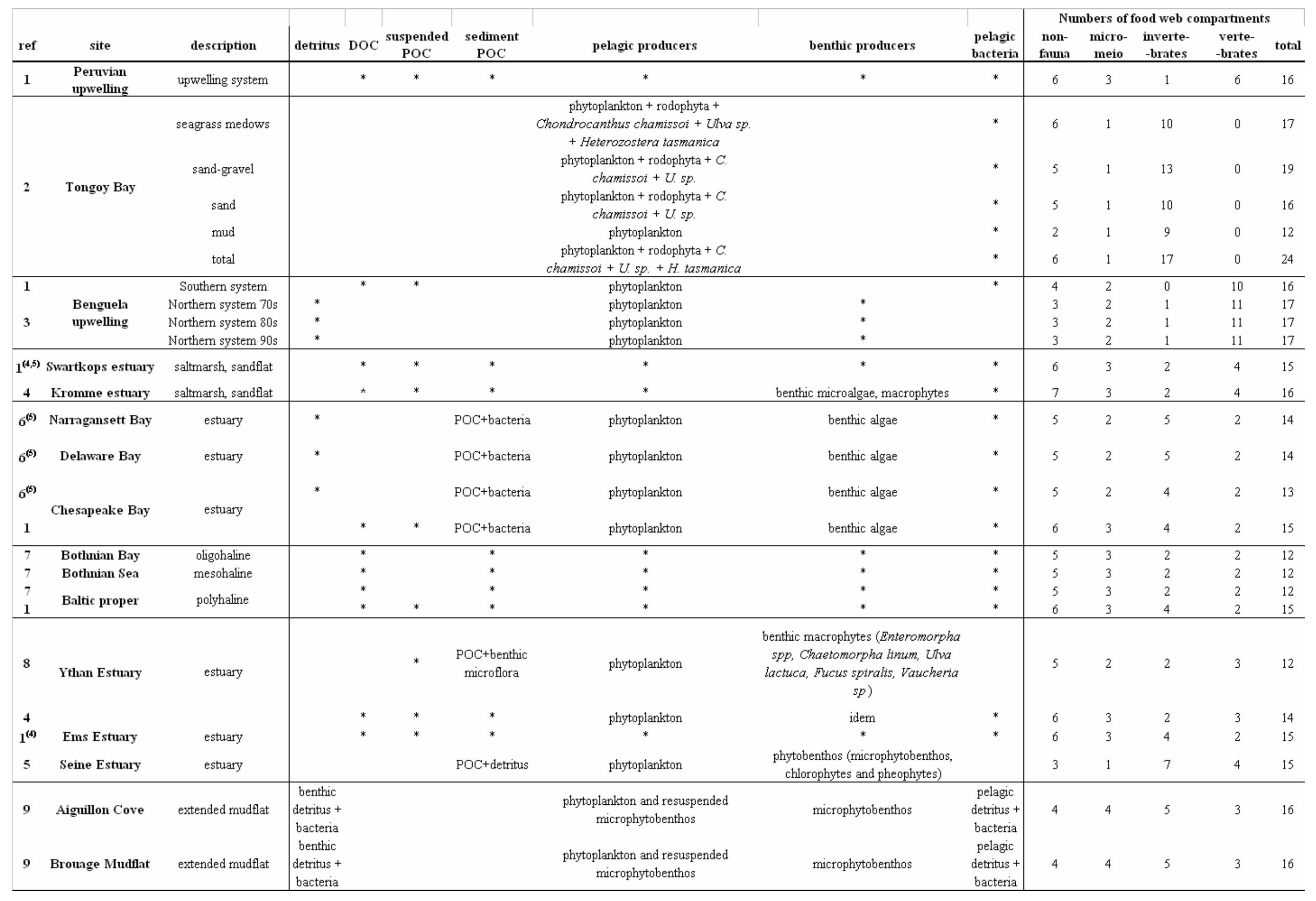




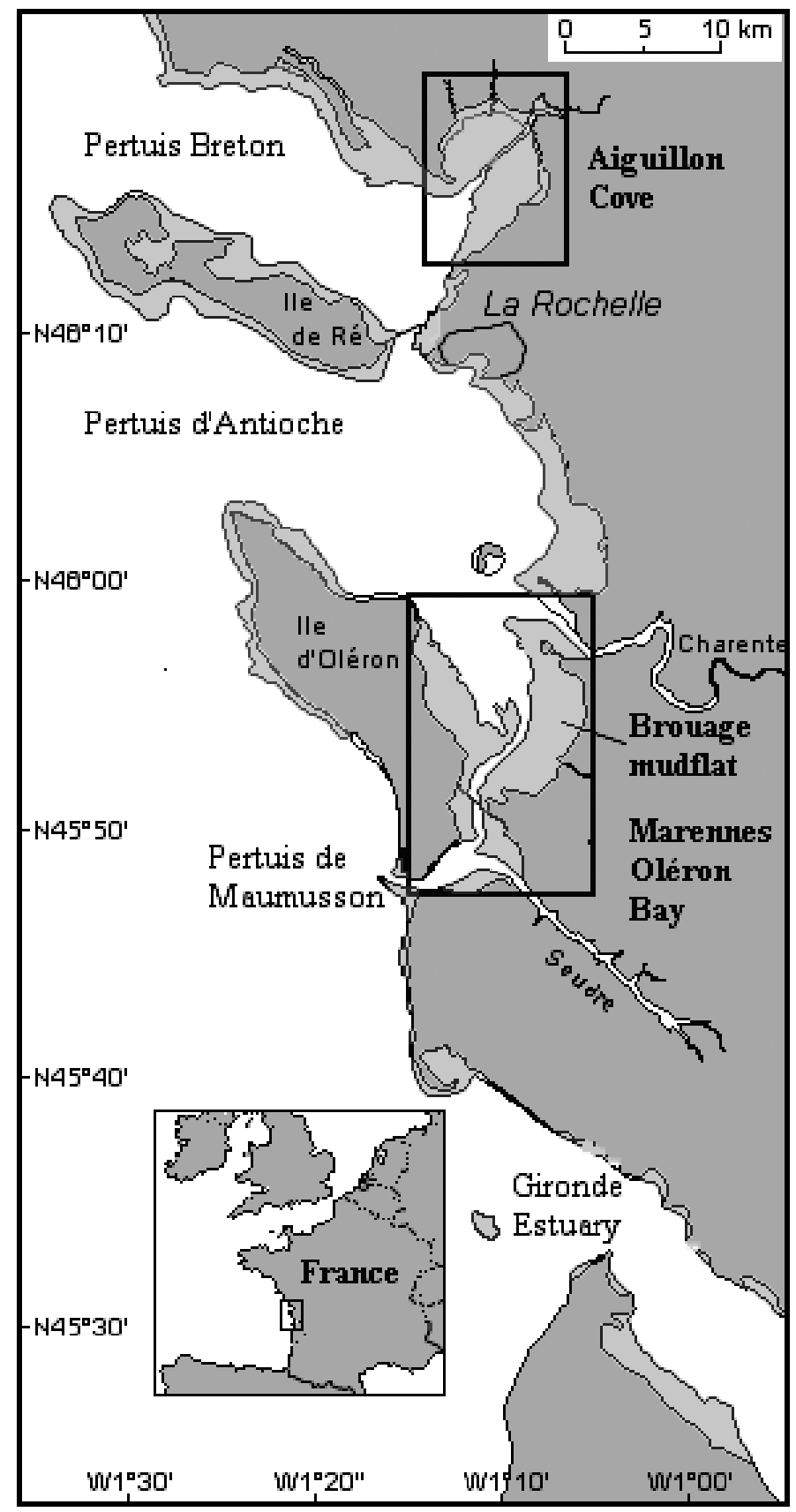

Fig. 1. Map of the Charentais Sounds (Pertuis) showing the location of the two study sites: the Aiguillon Cove and the Brouage Mudflat (from Degré et al.. 2006) 


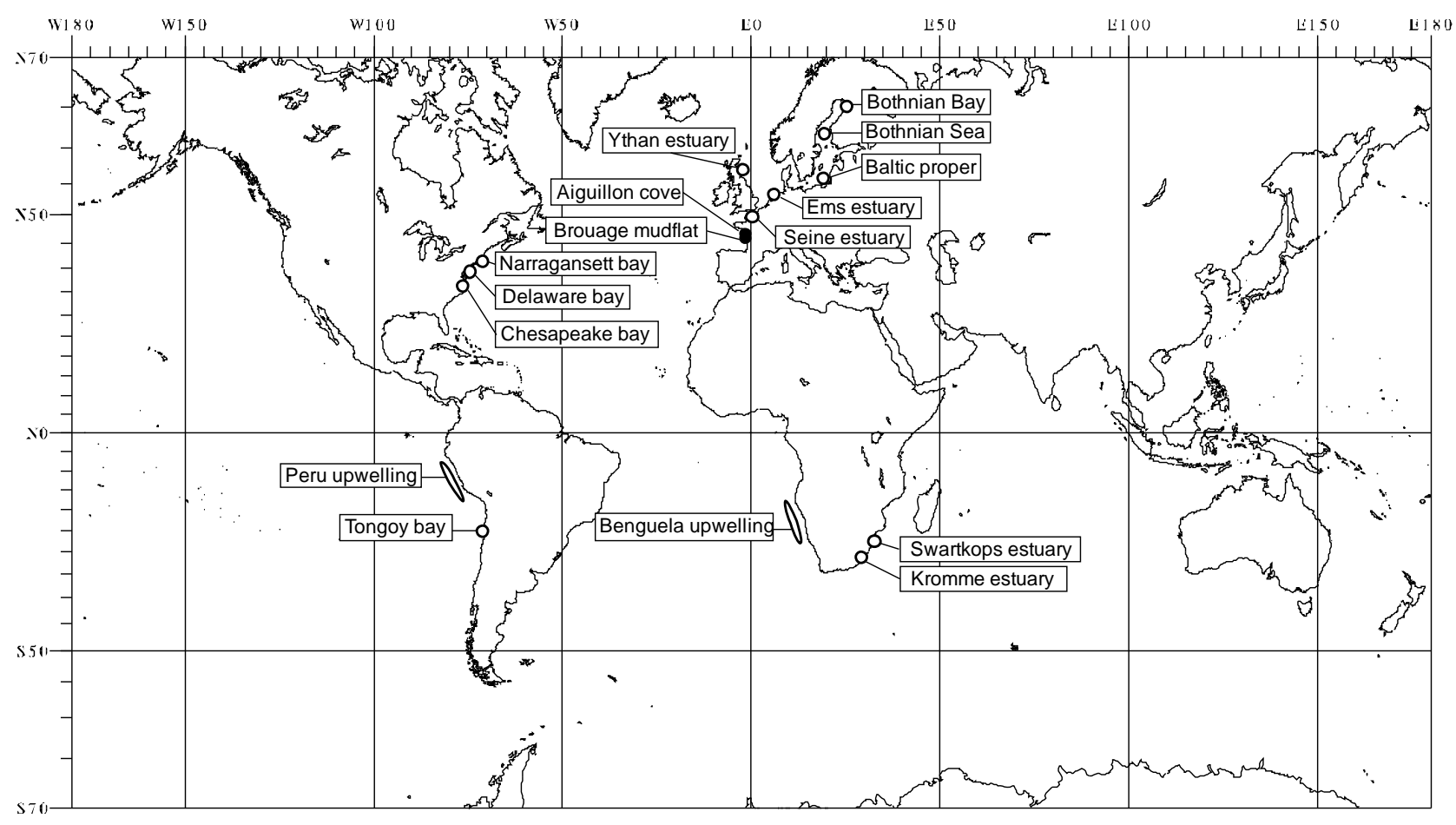

Fig. 2. Map of the world with the 2 French intertidal mudflats (Aiguillon and Brouage. black points). and the 14 compared sites (3 Baltic sites. 3 North-European estuaries. 3 American estuaries. 3 upwelling systems and 2 South-African estuaries. white points). 

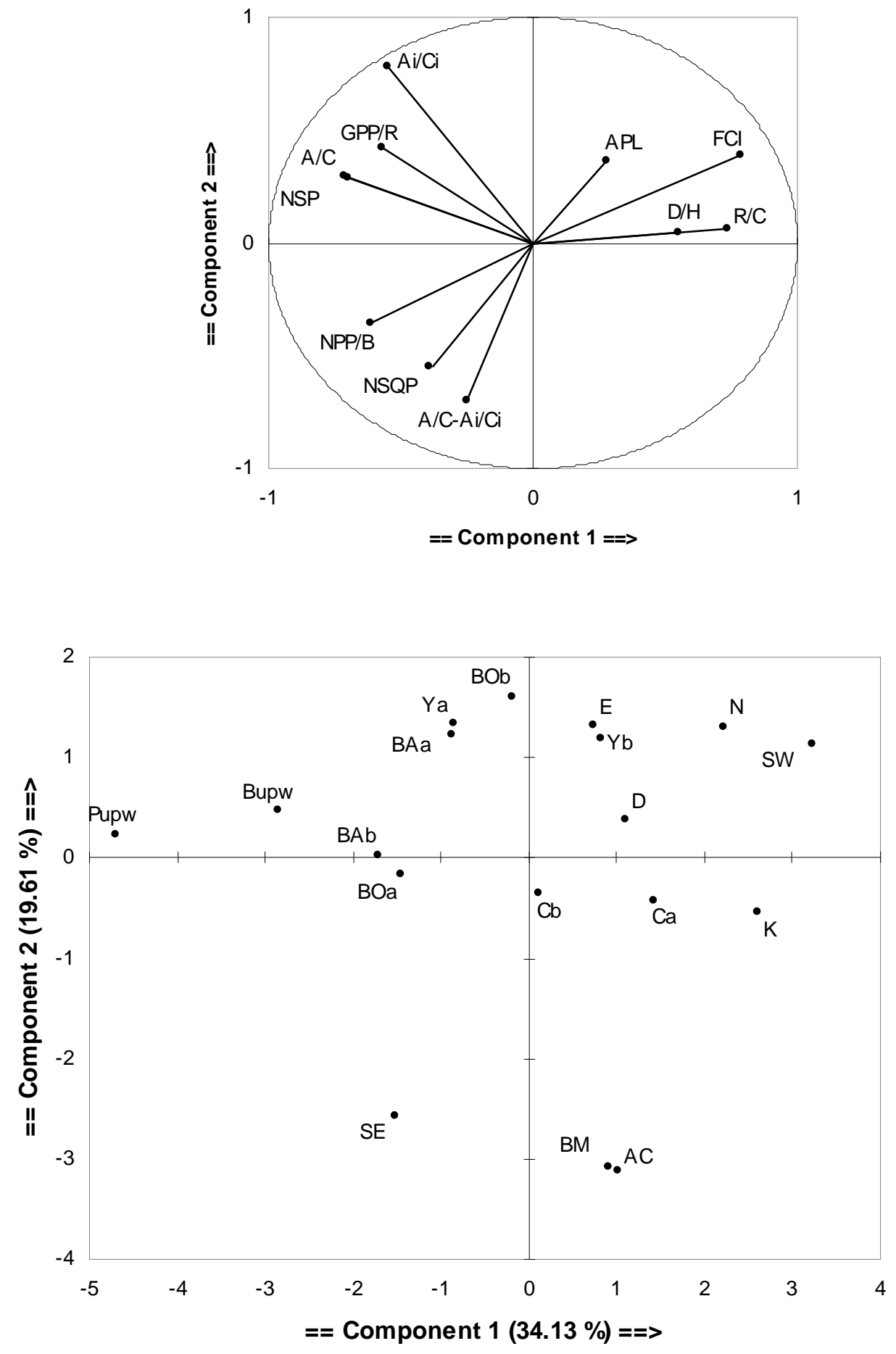

Fig. 3. Principal Component Analysis applied to the indices of Tab. 3. Upper part of the figure: scatter plot of the variables (network analysis indices) in the space defined by the 2 first components. Lower part of the figure: scatter plot of the observations (ecosystems). For indices and ecosystem abbreviations see Table 3. 